have expressed an opinion in favour of the existence of two planets at nearly the same mean distance. With respect to a period of twenty-eight days, we remark that reckoning from 1876 , April 4, it will agree with the observations of Lescarbault and Lummis, but not with that of Decuppis; while it also agrees with the observation of Stark, I8I9, October 9, a very definite one, which is not brought in with a period of forty-two days. The shorter period will be found to correspond with a mean distance of $0^{\prime} \mathrm{I} 8$.]

\section{SCIENCE IN SCHOOLS}

$7 \mathrm{HE}$ accompanying letter, signed by several men of Science and Head-masters, has been sent to the General Committee of the British Association :-

DEAR SIR,-It is hoped that a Committee may be formed at this year's meeting of the British Association for the promotion of Science Teaching in Schools. Its proposed functions would be--

I. To communicate with head-masters and governing bodies as to carrying out the recommendations contained in Report VI. of the Science Commission, and to offer advice, if required, on all necessary details of selection, arrangement, and outlay.

2. 'To press upon the Universities such steps in connection with the pending Bill in Parliament as may beneficially influence school teaching of science.

3. To watch the action of Government in any proposal made by them either in pursuance of Lord Salisbury's Bill or in giving effect to the Duke of Devonshire's Commission, and to hold a brief for science-teaching at schools in reference to all such legislation.

We desire to bespeak your attention to and interest in this proposal, which appears to us in all respects a timely one.

\section{THE BRITISH ASSOCIATION}

\section{GlasGow, Tuesday}

THE Association finds a fitting home in Glasgow, which has few rivals either in earlier or later scientific reputation. The force of long-continued scientific traditions, added to the present encouragement given to science, and I must also say, to the nearness of the finest holiday localities, makes this one of the most brilliant of recent meetings. Not only is the total number of members and associates attending very high, over 2,700 , but the true chiefs of science are present in great strength. It cannot be said that the Association itself is this year at all below its high aims. The majority of papers are really scientific, and do not emasculate the truth in the effort to popularise it. Discussions have been very interesting, judging from the perseverance with which they have been listened to. The reception given by the people of Glasgow is worthy of the city, although it is possible that in the details and refinements of arrangement, Bristol excelled. This was especially manifested in regard to some of the excursions. But it is evident that the very best efforts of the north have been put forth in every way, and the general result is undeniably successful. The charming situation of the University Buildings, in which all the sections but one hold their meetings, is a very great advantage.

From the Report of the Council it will be seen that grants in aid of scientific objects have been made during the year to the amount of $1,092 l$. The income of the year has reached $3,743 l$., and the cash balance, $764 l$., exceeded that of last year by $624 l$.

The President's Address did not excite general enthusiasm among the audience, partly because the great size of the building and the comparative weakness of the speaker's voice prevented many from hearing well, partly, also, because it was such as to impress most those who think most. The address manifested the combination in its author of qualities seldom marching together; deep regard for elder times and their achievements, wide knowledge of the position of science at the present day, perception of the true relationships, the real connexus of pure and applied science, a realisation, founded on careful study of the way in which the scientific cultus affects human nature, and the rise and fall of nations. It would be vain to seek for scientific arrogance and conceit in Dr. Andrews's deliverance, and if one may forecast, it may be expected to have as much influence on future thought and public action as almost any recent utterance from the presidential chair of the British Association, without any tendency to provoke the hostility of the unscientific.

Among the presidential addresses, that of Mr. Wallace to the Biological Section seems to have attracted much notice; and there is no doubt of its great value, for, scarcely occupying any ground covered by his recent great work on "The Geographical Distribution of Animals," he may be said to have laid the foundations of a new science out of "waste materials" already existing. Thus another group of scattered fragments is beginning to be sought by right processes, in order that a coherent edifice may be erected. Sir William Thomson returned again to the charge against the exorbitant demands of geologists for "time." If he is right, of course some geological theories must be altered; but perhaps Sir William will not have to wait long for an answer. It was singular that Prof. Young, in the Geolugical Section, should have chosen a subject agreeing so largely with Sir William Thomson's. His views, carried out into more geological detail, imply that we are to look for a general reconstruction of much that is held to be settled. in geological theory. He calls loudly for precision in geological phraseology, believing that there is nothing more urgently needed to secure progress in the science than some of that accuracy of conception and expression which distinguishes mathematical and physical science. Capt. Evans's address on Geography will perhaps disappoint some who think the questions of oceanic circulation are practically settled, but an open confession of difficulties and ignorance is better than any false security. Such confessions have been very general among the best men at this meeting-a favourable augury of coming victories for science.

On the whole the sections have done hard work, and comparatively little sacrifice of scientific rigour and form has been maade for the sake of making subjects popular. The Duke of Argyll's address on the Geology of the Highlands was a bonne bouche for the untechnical, and was much run after. The Duke has shared "lionship" with Commander Cameron and Sir C. Wyville Thomson; consequently the heart of Africa and the depths of the sea are among the favourite subjects here. Sir William Thomson has, of course, been at home on the great Tide question, denouncing the British Hydrographic Department for its supineness, by which very laborious and expensive efforts are left to private individuals. One of the most lively encounters has concerned the junction of the granites and Old Red Sandstone in Arran. It was suggested that Mr. Wünsch and Dr. Bryce should adjourn to the locality to fight it out, but without hammers. The chemists had a field-day on the disposal of the sewage of towns. Irrigationists and precipitationists continued their controversies, giving excuse to great towns still to postpone dealing with the subject. While the doctors, or rather chemists, differ, the sewage is emptied into the river.

Prof. Tait's discourse on Force was yery characteristic. One important advantage gained by the audience would probably be an impression of the necess: : of accuracy in the use of words.

Sir C. Wyville Thomson's address on tis Results of 